\title{
Students' Perception toward Implementation of Metacognitive Strategy in Higher Education
}

\author{
Novitasari \\ Politeknik Negeri Malang \\ Novitasari@polinema.ac.id \\ Nur Mafissamawati Sholikhah \\ Universitas Muhammadiyah Malang \\ Nur.mafissa@gmail.com
}

\begin{abstract}
Metacognitive strategy is described as a thinking strategy of gaining knowledge and comprehension by knowing what students know and what they do not know. Since college students struggle to be successful in their study, they should have an awareness of applying this strategy in learning, so it can empower them to think about their own thinking process, enhance their control over their learning, and increase their autonomy to reach the goals. Therefore, teachers should consider incorporating metacognitive strategies in designing a lesson plan. This study aims to investigate the students' perception toward metacognitive strategies used in class. It was done in two classes in D3 English Department. The participants consist of 49 students. Data was gained from distributing questionnaire to students after metacognitive strategies was applied in the class. There are two types of data, quantitative and qualitative data. The quantitative data was analysed using descriptive analysis, the qualitative data was described in depth analysis and summarized. The results found that most of the students had positive perception toward metacognitive strategies in the class. However, they found some challenges in implementing the strategies in their study.
\end{abstract}

Keywords: metacognitive strategies, higher education, students' perception

\section{Introduction}

The demand in higher education has challenged the students to acquire more skills and knowledge to solve many complex problems during their study. They are asked to have analytical skills, increase ability to deal with new information, and draw independent conclusion. Another challenge for the students is learning lesson with less guidance or help. Mckendry and Byod (2012) state that the students in higher education are required to become independent learners in all aspects. 
However, many students struggle to make the transition from their previous study to the more independent required at higher education level. Higher education system requires students to take responsibility for their own learning, to be more self-directed, and to make choices about what they will concentrate on and how much time they will spend learning both within and outside the classroom. Hence, they need some learning strategies to make learning more effective and efficient that can lead them to success.

Learning strategy can be categorized as one of the most important factors in learning process. It helps students to overcome their weaknesses in learning. Besides, learning strategy will also strengthen the memory when they want to retrieve information stored in their memory. According to Richards \& Schmidt (2002), language learning strategies are classified into four types: management, social, cognitive, and metacognitive. Management strategies refers to variety of strategies used to keep students organized, orderly, and focused such as setting the properties that will be used and the time and place when studying a language. Meanwhile, they define social strategies are where the students seeking for friends or native speaker to share and to practice. Another strategy is cognitive strategies which are described as the process by which students compare and organize information. Lastly, metacognitive strategies are modes of thought that include planning, deciding on approaches, and evaluating.

Metacognitive strategy is a method used to help students understand the way they learn. It encourages students to understand how they learn best by organizing the way the brain needs to organize it specifically through learn information, store 
it on memory, and retrieve it whenever they need it. It really fosters students organize information in ways that support their abilities to remember.

It is believed that successful knowledge acquisition requires the use of metacognitive skills. A large number of studies have discussed the impact on implementing metacognitive strategies to students' behaviour and success. It also helps students improve their learning skills in formal educational settings. In the process of metacognitive strategy, the learners will organize their own plans, monitor their progress in learning, and evaluate the learning process. For the abovementioned reasons, this study intends to investigate students' perception on the implementation of metacognitive strategies.

\section{Literature Review}

Metacognition is often referred as "thinking about thinking" or "cognition about cognition". This term was firstly coined by Flavell (1979), who then has regarded as a founder of research in metacognition. Over the time, the concept of metacognition expanded to define it as knowledge, awareness, control on one's own cognition, and control on one's own learning (Tarricone, 2011). In the same light, Tavakoli (2014) and Tobias and Everson (2002) also claim that metacognition refers to higher order thinking skills which require one to process knowledge cognitively, evaluate what lesson they have learnt and have not learnt, and constitute an attempt to regulate their own learning. In general, there are three mental activities involved in metacognition; awareness, monitoring, and regulating. Simply put, metacognitive strategies are the strategies which intend to raise one's awareness and control of their thinking processes whether or not they can 
comprehend the lesson learnt, to improve learning skills and comprehension, and to evaluate whether or not the comprehension have been successful.

\section{Benefits of Metacognitive Strategies}

The existing literature has a lot to offer in terms of the benefits of metacognitive strategies on learning process. The most renowned one is metacognitive strategies will shape students becoming more independent on their learning process (Van Velzen, 2016). In line with this, Shanon (2008), Goctu (2017), and Cher (2019) support that metacognitive strategies with metacognitive instructions encourage students to become more self-directed and autonomous who are able to plan, monitor, and evaluate their learning as well as keeping their comprehension on track. Therefore, the students will become more successful in the long run.

Moreover, metacognitive strategies have crucial roles in helping students to solve problems. When students have been taught a set of procedures and strategies, they will be able to use specific strategies when encountering difficulties (Dole, 2003). Keiichi (2000) also adds the point on the importance of metacognitive skills. Problem solving tasks will be much easier for students when they have metacognitive strategies in which allowing students to set the goals of the tasks, to manage their thoughts, and to put them in the right direction.

In Indonesian context, a number of investigations have been done in employing metacognitive strategies to teach several skills in English language including reading, listening, and writing. Most of the researches showed a positive result on the use of metacognitive strategies to students in higher level of education. For example, Mbato (2013) who conducted a study on metacognitive strategies in 
reading class in the level of higher education found that the university students were more self-regulated in their reading class. Another study conducted by Fiani et. al., (2018) on the implementation of metacognitive strategies in EFL listening also demonstrates that the students benefited various effective metacognitive strategies to improve their ability in listening and to help them more successful language learners. More recent research by Fiani (2020) in writing class also showed that students had relatively positive response to the teaching program using metacognitive strategies. Students obtains numerous benefits to shape them to be independent and successful learners in writing.

\section{Teaching Using Metacognitive Strategies}

The conceptualization of metacognitive strategies typically involves one or more aspects of a cognitive process namely knowledge about process, the monitoring of the process, and the control of the process (Sera \& Metcalfe, 2009). These aspects have been used in teaching reading comprehension which are divided into three steps including planning, monitoring, and evaluating.

\section{Planning}

Every learning process requires a set of plans in order to obtain a success. Reading generally involves three main activities; pre-reading, whilst-reading, and post-reading. In applying metacognitive strategies, planning takes place in the prereading activity. In the course given, students are required to think about the reading topic and other features that might help them to get a preliminary idea about the content of the text. Figures, charts, and headings also contributes to help students 
in making predictions about the content of the text as the planning strategy (Harris, Santangelo, \& Graham, 2010).

\section{Monitoring}

Monitoring happens in the phase of whilst-reading in which students monitor their comprehension during reading. Fogarty (1994) mentions that there are numerous ways and strategies that can be used to do monitoring in reading such as making predictions, making connections, using context clues, identifying text structures, etc. Examining difficult words and answering the exploration questions are also the example of strategies in monitoring the comprehension (Othman, Mahamud \& Jaidi, 2014)

\section{Evaluating}

The last step is evaluating which takes place after the main activity of reading. Zimmerman and Pons (1986) state that strategies for evaluation are for measuring the quality or progress of students' work. Moreover, it also has several purposes such as collecting feedback, doing assessment, and making conclusion.

The illustration of the implementation of metacognitive strategies in teaching reading comprehension can be seen as follow (adapted from Othman, Mahamud \& Jaidi, 2014, p.104): 


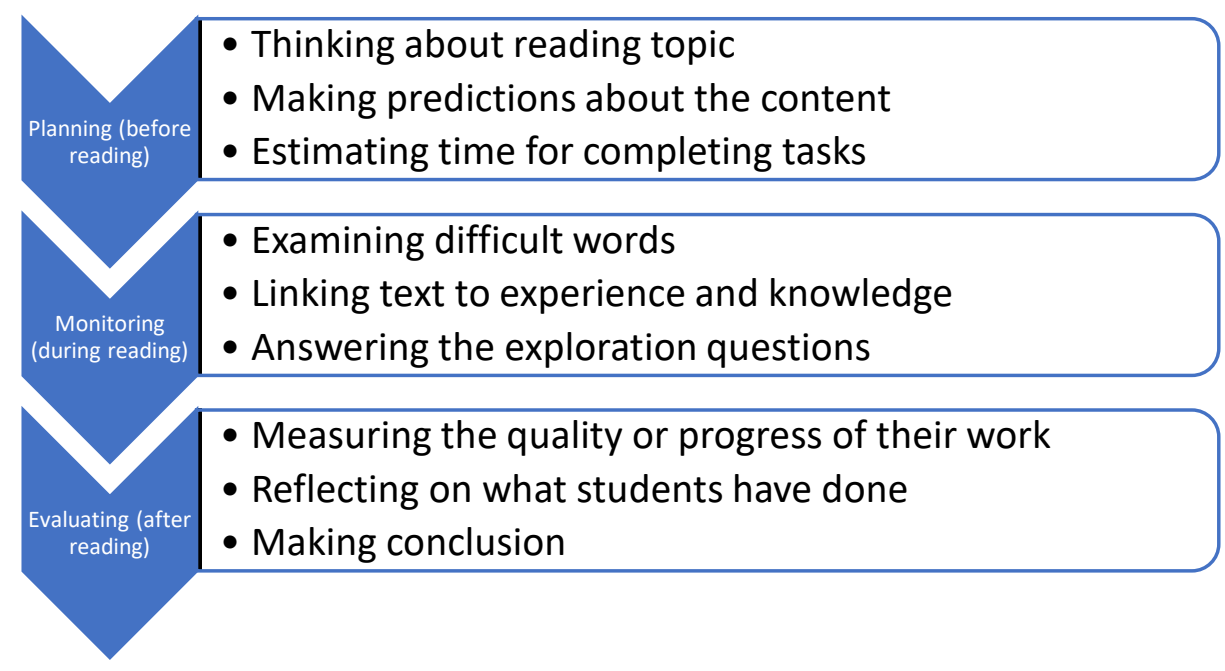

Figure 1. The Implementation of Metacognitive Strategies in Reading Comprehensio

\section{Examples of Metacognitive Strategies}

There are several suggested metacognitive strategies that teachers used to foster students' metacognition. Two strategies are given in the following discussion.

\section{Matrix Organizer}

Matrix organiser basically consists of rows and column that can be filled by students to organize information and compare different information in one or two categories (Peteranetz, 2016). This strategy allows students to easily compare and contrast the information from a given text, to observe differences and similarities that they want to investigate further, and to comprehend what they are reading. By doing this, the students will be able to remember information easily and see relationships within the information.

\section{Mind-mapping}

Mind mapping is known as the effective technique in teaching any subject. According to Buzan and Buzan (2002), mind mapping is an activity to map and 
record information to make it stored properly in memory using colours, images, and symbols. In keeping with given definition, mind mapping is also defined as a technique for drawing relationships between concepts which lets students to make pictures, draw a line, and play with colours (Farrand, Hussain, \& Hennessy, 2002). Davies (2011) also adds that pictures and diagrams in colour are easier to understand the complex topic than words, to make learning more fun, to organize the ideas, interpret the concepts and to facilitate meaningful learning.

\section{Method}

This study applies mixed method because it tries to investigate the students' perception and describe challenges toward the implementation of metacognitive strategies in class. The research was conducted in two classes at D3 English Department in Politeknik Negeri Malang. The total respondents are 49 students.

Firstly, the students were taught by implementing metacognitive strategies such as matrix organizer and mind mapping activities in 4 meetings with different topics. In every implementation, the researcher applied three stages in metacognition namely planning, monitoring, and evaluation. The students were given the material in the form of text and module they must put the information from the text into table in two meetings. At the third and fourth meeting, the students were instructed to design free mind map based on the text given. There was an evaluation after the activity done to check students' understanding about the material. At the end of the implementation, the researcher investigates their response by distributing questionnaire. 
This research was analysed using mixed-methods in two stages. First, quantitative data were collected through questionnaire survey to explore various students' perceptions on the implementation of metacognitive strategies in the classroom. To distribute a questionnaire in the main study, Google Forms was used. The researcher copied the link provided and paste it in WhatsApp group so the participants would be able to access it easily. The responses then were immediately documented into a spreadsheet and analyzed.

Second, the qualitative data were collected through open questions from questionnaire. It consists of questions with brief answer and the respondents could answer them based on their own experience and give additional information about what have been stated in closed questions.

\section{Result and Discussion}

A set of questionnaires was prepared in order to find out students' response and to inquire whether the implementation of metacognitive strategies was beneficial for them. The questionnaire involved the process of metacognition as well as students' views on the metacognitive strategies.

There are two types of questionnaire, close-end questions and open questions. The close-end questions were used to find out students' perception of the implementation of metacognitive strategies in class. Below is the result.

\begin{tabular}{|c|c|c|c|c|c|}
\hline & \multirow[t]{2}{*}{ STATEMENT } & \multicolumn{4}{|c|}{ RESPONSE } \\
\hline & & $\begin{array}{c}1 \\
\text { Very } \\
\text { disagree }\end{array}$ & $\begin{array}{c}2 \\
\text { Disagree }\end{array}$ & $\begin{array}{c}3 \\
\text { Agree }\end{array}$ & $\begin{array}{c}4 \\
\text { Very } \\
\text { Agree }\end{array}$ \\
\hline 1 & $\begin{array}{l}\text { Sebelum memulai mengerjakan tugas, saya } \\
\text { sudah memiliki gambaran apa yang harus saya } \\
\text { lakukan pertama kali. }\end{array}$ & $4.3 \%$ & $19.1 \%$ & $29.8 \%$ & $47.3 \%$ \\
\hline
\end{tabular}




\begin{tabular}{|c|c|c|c|c|c|}
\hline 2 & $\begin{array}{l}\text { Sebelum memulai mengerjakan tugas, saya bisa } \\
\text { memperkirakan berapa lama saya } \\
\text { menyelesaikan tugas ini dengan lengkap. }\end{array}$ & $10.4 \%$ & $52.1 \%$ & $29.2 \%$ & $8.3 \%$ \\
\hline 3 & $\begin{array}{l}\text { Ketika mengerjakan tugas, saya tahu bahwa } \\
\text { saya berada di jalur yang benar. }\end{array}$ & $2.1 \%$ & $8.3 \%$ & $68.8 \%$ & $20.8 \%$ \\
\hline 4 & $\begin{array}{l}\text { Ketika mengerjakan tugas, saya tahu apa yang } \\
\text { harus saya lakukan jika saya tidak mengerti. }\end{array}$ & $2.1 \%$ & $8.3 \%$ & $66.7 \%$ & $22.9 \%$ \\
\hline 5 & $\begin{array}{l}\text { Model pembelajaran menggunakan } \\
\text { metacognitive membantu saya } \\
\text { mengorganisasi informasi dengan baik }\end{array}$ & - & $8.3 \%$ & $37.5 \%$ & $54.2 \%$ \\
\hline 6 & $\begin{array}{l}\text { Model pembelajaran menggunakan strategi } \\
\text { metacognitive membantu saya mengingat } \\
\text { informasi penting }\end{array}$ & - & $10.4 \%$ & $31.3 \%$ & $58.3 \%$ \\
\hline 7 & $\begin{array}{l}\text { Model pembelajaran menggunakan strategi } \\
\text { metacognitive membuat saya tahu cara } \\
\text { menerapkan metode ini ke masalah lain }\end{array}$ & - & $16.7 \%$ & $56.3 \%$ & $27.1 \%$ \\
\hline
\end{tabular}

Table 1. Students' response on the perception of metacognitive strategy

From table 1, the result reveals that students supported the application of metacognitive strategies in class. Overall, students give positive perception on the implementation of metacognitive strategy in class. The detailed response can be described as follows:

\section{Planning}

It is about $47.3 \%$ very agree that they already understood what they did before applying the strategy. However, $52.1 \%$ of students cannot predict how long they will fulfil the assignment completely.

\section{Monitoring}

The percentage of students who agree that they are in the correct procedure when doing the assignment is around $68.8 \%$. It is about $66.7 \%$ students who know what should do when they found problem in doing the assignment.

\section{Evaluating}

More than 50\% students found that metacognitive strategy helps them to organise the information better and to remember the relevant information. There are $56.3 \%$ 
students stating that they know how to apply the strategy on other problems or situation.

The researcher also distributed open-question questionnaire to find out the benefits and students' challenge toward the implementation of metacognitive strategy in class.

\section{Benefits of metacognitive strategy}

Regarding to the benefits learning activity as metacognitive strategy, the students are asked with the question "What are other benefits of using mind mapping activity?" to reflect on the implementation of mind mapping as metacognitive strategy. The following are the students' statements when they are asking about the benefits of metacognitive strategy that had been applied:

"The learning process is easier and mind mapping can help you understand a concept or material as a whole" (S1)

"I can remember the information and understand the point better" (S2)

The students' statement on the benefit of mind mapping activity as metacognitive strategy showed a positive response. After engaging in the mind mapping activity which involved three steps (planning, monitoring, and evaluating), the majority of students got many positive effects such as they found easier to understand the concept and material as a whole and they could remember the information better. This is in accordance with the result from Buzan and Buzan (2002), stating that mind mapping can be an innovative and effective method in remembering things better.

Besides, mind mapping activity also helped them to complete the task easily with relatively short time, to catch information by themselves, as well as making students easier in organizing the ideas. Students 3, 4, and 5, for instance, mentioned: 
"I can catch the important information easily without help from others and having to read the entire book" (S3)

"Mind mapping makes me more understand the material by connecting the information" (S4)

"It makes easier to organize some information or material" (S5)

Fun and Maskat (2010) also found that mind mapping activity as metacognitive strategy is helpful to brainstorm and organize the ideas, which in turn contributes to better comprehension of the text. Another benefit of mind mapping as metacognitive strategy is helping students become independent learner. Ren and Jiang (2019) assert that students who are taught metacognitive strategy can be more independent in learning without getting assistance from others.

Overall, the benefits found in this study are the students can remember the information better, organize the information well, catch information without help from others, get better understanding about the material, and shape students to be independent learner.

\section{Challenges of metacognitive strategy}

Not only benefits did the students gained from the implementation of metacognitive strategy, but they also got some challenges in applying the strategy. The following are the students' statements"

"I got problem to determine the points that must be included in table/map" (S1) "It's quite difficult to choose the important information and deliver it briefly" (S2) "Make the information concisely" (S3)

"Sometimes I found difficult to explain detailed information using simple phrase" (S4)

"Lay outing and designing the mind map to make it more organised and attractive"

"Time allotment is quite short so I need more time to maximize the assignment"

The responses indicate that the challenges are stated mostly in simplifying the information in the text, making template for the mind mapping, and having less 
time to accomplish the map. The students suggest that the mind mapping activities can be done using PC and some digital tools so it will make them easier to put the information in the template provided. They also propose to get more time to accomplish the assignment given.

\section{Conclusion}

Metacognitive strategies should be taught for higher education students to improve their literacy skills and give more positive effects to students such as becoming independent learner, better in organizing ideas, and in remembering information. However, it's important to put in more thought to every stage of metacognition including planning, monitoring, and evaluating to assist students in acquiring metacognitive skills.

The finding also has pedagogical consequences for lecturers in terms of the relevance of integrating language learning strategies to foster students' success in learning; thereby, lecturers or curriculum developers may incorporate language learning strategies in the design of the lesson plan or material.

\section{REFERENCES}

Buzan, T., \& Buzan, B. (2002). How to mind map. London: Thorsons.

Cher, E. (2019). The Instruction of writing strategies: the effect of the metacognitive strategy on the writing skills of Pupils in secondary education. SAGE Open, 1- 17.

Davies, M. (2011). Concept mapping, mind mapping and argument mapping: what are the differences and do they matter?. Higher education, 62(3), 279-301.

Dole, J. A. (2003). Comprehension Strategies. Department of Teaching and Learning University of Utah: Macmillan/McGraw-Hill. 
Farrand, P., Hussain, F., \& Hennessy, E. (2002). The efficacy of themind map'study technique. Medical education, 36(5), 426-431.

Fiani, A. (2020). Students' perception toward the enactment of metacognitive instruction in an efl writing class: lesson learned from a private university in Indonesia. Research and Innovation in Language Learning, 3(3), 220233.

Fiani, A., Suherdi, D., \& Musthofa, B. (2018). The impact of metacognitive instruction on EFL students' listening comprehension and metacognitive awareness in Lubuklinggau. Advances in Social Science, Education and Humanities Research (ASSEHR), 188, pp. 134-140.

Flavell, J. H. (1979). Metacognition and cognitive monitoring: A new area of cognitive- developmental inquiry. American Psychologist, 34(10), 906-911.

Fogarty, R. (1994). How to teach for metacognition. Palatine, IL: IRI/Skylight Publishing.

Fun, C. S., \& Maskat, N. (2010). Teacher-centered mind mapping vs studentcentered mind mapping in the teaching of accounting at pre-U Level-An action research. Procedia-Social and Behavioral Sciences, 7, 240-246.

Goctu, R. (2017). Metacognitive Strategies in Academic Writing. Journal of Education in Black Sea Region, 2(2), 8-9.

Harris, K. R., Santangelo, T., \& Graham, S. (2010). Metacognition and strategies instruction in writing. Metacognition, strategy use, and instruction, 226-256.

Keiichi, Shigematsu. (2000). Metacognition in Mathematics Education. Mathematics Education in Japan. Japan: JSME, 2000.

Mbato, C., (2013). Facilitating EFL learners' Self-regulation in Reading: Implementing a Metacognitive Approach in an Indonesian Higher Education Context. Ed D thesis, Southern Cross University, Lismore.

Mckendry, S., \& Boyd, V. (2012). Defining the "Independent Learner" in UK Higher Education: Staff and Students' Understanding of the Concept. International Journal of Teaching and Learning in Higher Education, Volume 24, Number 2, 209-220 
Othman, Y., Mahamud, Z. \& Jaidi, N. (2014). The Effects of Metacognitive Strategy in Reading Expository Text (pp.102-111). Published by Canadian Center of Science and Education.

Peteranetz, M. S. (2016). Fostering metacognition in K-12 classrooms: Recommendations for practice. The Nebraska Educator: A Student-Led Journal, 31, 64-86.

Ren, Y., Jiang, X. (2019). A Mind Map Teaching Mode for Sports Anatomy Based on 3D Body. International Journal of Emerging Technologies in Learning Vol. 14, No. 10: 4-17. https://doi.org/10.3991/ijet.v14i10.10776

Richards, J.C. and Schmidt, R. (2002). Longman Dictionary of Language Teaching \& Applied Linguistics (3rd edition). Essex: Pearson Education Limited.

Sera, M. J \& Metcalfe, J. (2009). Effective Implementation of Metacognition. In Hacker, D. J., Dunlosky, J., \& Graesser, A. C., (2009). Handbook of Metacognition in Education (pp. 278-298). New York: Routledge.

Shannon, S. V. (2008). Using metacognitive strategies and learning styles to create self- directed learners. Institute for Learning Styles Journal:1,14-28. Retrieved from www.auburn.edu/.../Journal\%20Volumes/.../...

Tarricone, P. (2011). The taxonomy of metacognition. Psychology Press.

Tavakoli, H. (2014). The effectiveness of metacognitive strategy awareness in reading comprehension. The Reading Matrix, 14(2).

Tobias, S. \& Everson. H. T. (2002). Knowing what you know and what you don't: Metacognitive knowledge further research on monitoring. College Board Research Report, 2002-3.

Van Velzen, J. (2016). Metacognitive learning: advancing learning by developing general knowledge of the learning process. Switzerland: Springer International Publishing.

Zimmerman,B.J., \& Pons, M.M. (1986). Development of a Structured Interview For Assessing Student Use Of Self-Regulated Learning Strategies. American Educational Research Journal, 23(4),614- 628. 